\title{
The Idea of Open Borders: For and Against
}

\author{
Kebadu Mekonnen*
}

\begin{abstract}
The issue of immigration has gained tremendous attention in recent literature on political theory. It evokes debates among different traditions in political theorizing- liberal egalitarianism, libertarianism and communitarianism to mention the main theoretical camps. What position one is likely to take concerning immigration depends upon one's general view about the nature of the state, what membership to a political community constitutes and about the legitimacy of state borders. This paper examines the discord of opinions that has marked recent discourses on immigration. After a careful examination of the positions taken by main contributors to the debate, namely Joseph Carens, Brian Barry, Hillel Steiner, Michael Walzer and Onora O'Neill, this paper employs the principle of moderation which Aristotle has advocated back in antiquity. Carens' position is here taken as a point of departure, from where each point of view is weighed against without taking his position for granted. By way of comparative analysis the weaknesses, or at any rate the failure, of Carens' extreme position can be unravelled. Extreme positions, argument for open borders (as Carens advocates) and a claim for absolute sovereignty, are doomed to fail: they are both theoretically flawed as well as not feasible in the world we live in. Given the conception of the political in the form of state, as it is currently in order, a plausible immigration policy ought not undermine the legitimacy of state borders- without which no political community could be conceived of, without at the same time giving absolute value to sovereignty.
\end{abstract}

Keywords: state borders, immigration, egalitarianism, libertarianism, communitarianism

\section{A case for open borders from a liberal egalitarian point of view}

In this section of my essay I will discuss an argument for open borders by Joseph Carens. In his attempt to defend the idea of open borders, he took the liberal egalitarian point of view for granted. It is this basic assumption that led him to advocate the idea of open immigration that he took the liberal idea as unshakable foundation for the inference he

\footnotetext{
*Assistant Lecturer, Department of Philosophy, AAU
} 
made. He invokes the fundamental values or principles upon which liberalism as a comprehensive moral theory rests and which liberal societies recognize as shared social values, as a point of departure. He contends that in principle borders should be open and that people, irrespective of their racial, social or national origin, should be free to leave and settle in another country, "subject only to the sort of constraints that bind current citizens in their new country”. (Careens 1995: 332) Freedom of movement, he pronounces, is, or at least derived from, a widely shared value among liberal societies. Later I will take up two ways of refuting his claim, one by challenging the inference while leaving his premises unassailed and second by rejecting the liberal assumption outright. I would prefer to do so by way of challenging his inference, if succeeds that should render the second way irrelevant.

In his article, "Aliens and Citizens: The Case for Open Borders", Carens discusses what the three major approaches to political theory: Robert Nozick's libertarianism, John Rawls, and the utilitarians, have to say concerning immigration. This search for confirmation, to the claim for open borders, from other theoretical traditions could be called- to use Rawls' notion- a search for an 'overlapping consensus'. He first considers Nozick's account of the minimal state and took it as a background for the possible immigration policy it implies. Generally Nozick and his fellow libertarians like Hillel Steiner confine the role of the libertarian state to the protection of property and contractual rights, nothing more and nothing less. (Hillel 1992: 87-940) The territorial claims of a state is not different from that of individuals, so the argument runs, because the legitimacy of state borders rests on the property rights of the individuals comprising it. In other words, a state's legitimate claim for territory extends until the furthest members' property claims could capture. Territorial boundaries of states possess no more moral weight than "the boundary between my neighbour's land and mine". (Ibid: 93) So libertarians opted for a minimalist state; and thus citizenship rights would not be as expansive as the ones enjoyed by current citizens of liberal states. The right of individuals to enter into voluntary transactions is granted as individuals, not as citizens. When it comes to the issue of immigration, neither the state nor citizens as a group would be authorized to determine whether they should take in immigrants or not: it is solely the business of the individual to let either his fellow citizens or strangers step into his property. Under the libertarian system, no differential treatment shall be made between citizens and aliens; it seems individuals somehow remain alien to one another even after the social contract replaces the state of nature. That may explain why libertarianism is legitimately accused of killing communal or national sentiments. So in principle there will be no restriction on immigration by the state nor is it the duty of the state to facilitate immigration.

It could, however, be the case that "individual property owners could refuse to hire aliens, to rent them houses, to sell them food, and so on, but in a Nozickean [libertarian] world they could do the same things to their fellow citizens....But they have this right to exclude as individuals, not as members of a collective". (Carens 1995: 333-334) But I do not see the reason why Carens takes Nozick's conception of the state as providing support for the claim he stood for. Nozick's theory may imply that immigration restrictions by the state are not justified, but it doesn't follow straightforwardly from this that the state should be committed for opening borders; borders would be unsteady in the libertarian world 
anyway depending on the possible change of allegiance by individuals. Libertarians contend that the state has no right either to open or close national boundaries because the boundaries are nothing more than the sum total of individual properties of the people constituting the state. The sum total of individual decisions of citizens may turn out more restrictive on immigration than the current approaches on immigration taken by the United States or Canada. I don't need to refute the libertarian conception of the state in order to show that Carens is wrong- for our purpose it is enough to show that libertarianism does not imply open immigration.

Carens then moves on to the political theorist whose ideas he finds illuminating- John Rawls. He seems to be interested in 'domesticating' Rawls' idea of the 'original position' for the purpose of justifying the claim for open borders. Rawls made it clear that the original position is an 'initial choice situation' designed to take out morally arbitrary elements from determining principles of justice in which people are required to choose under the 'veil of ignorance'- "a situation in which everyone is deprived of... the knowledge of those contingencies which set men at odds and allow them to be guided by their prejudices”. (Rawls 1971: 19) Under this condition of equality people would choose two principles: the first which guarantees equal liberty to all and the second would allow inequalities in as much as they were to the advantage of the worse off (the difference principle). Any assembly of people constrained by the 'veil of ignorance', i.e. in purely rational state of mind would choose the same two principles. In total agreement with Rawls, Carens maintains that "a fair procedure of choosing principles of justice must therefore exclude knowledge of these circumstances, just as it excludes knowledge of one's race or sex or social status. We should therefore take a global, not a national, view of the original position”. (Carens 1995: 335) The globalised version of the original position, Carens supposes, would result in two principles parallel to the ones governing domestic situation: equal liberty across the board and global difference principle. So what about immigration? From the presumption that the right to move freely within a domestic territory being an important liberty, so the analogy goes, the second original position would approve free movement across borders.

According to Carens, free movement is an important liberty in itself subject to the very Rawlsian public order constraint (liberty may be deprived for the sake of liberty). But it is unreasonable to suppose that unrestricted migration would threaten public order, provided that all states were subjected to the first original position. So, in a world constituted by just states pursuing international difference principle, "the likelihood of mass migrations threatening to the public order of any particular state seems small”. (Ibid: 337) Even in non- ideal situations where we live under unjust conditions, natural and social circumstances play a role in determining one's life chances and people fail to live up to principles of justice, our immigration policy would be much less restrictive than the one currently in practice. This would surely be the case were we to impose only those restrictions necessary to maintain public order.

In accordance with the liberal tradition advocated by Rawls, restrictions could not be justified on the grounds that immigration negatively affects the welfare level of current citizens. For one thing inequalities are allowed to the extent that they serve the least welloff and for another if we take interstate immigration as an important liberty, as Carens 
does, the priority of liberty under Rawls' conceptual framework disqualifies such an objection from welfare. As far as I am concerned, I doubt that Carens' straight forward universalization of the original position is essentially Rawlsian. Rawls' second original position, the notion which came out lately as a restatement of his political theory in ways relevant to global justice, is intended to serve a totally different purpose and is situated in a different setting. At the international level, "the idea of the original position is used again, but this time to extend a liberal conception to the Law of Peoples". (Rawls 1999: 32) In The law of Peoples, which was written after Carens' paper was published, Rawls underlines the importance of state boundaries as he said, "[i]t does not follow from the fact that boundaries are historically arbitrary that their role in the Law of Peoples cannot be justified. In the absence of a world- state, there must be boundaries of some kind”. (Ibid: 39) The only thing well- ordered societies owe to societies burdened by unfavourable conditions is the duty of assistance- which is a requirement of justice; but the law of peoples does not require well ordered societies to open up their borders to whoever wants to enter. To this objection, Carens would respond by conceding that none of the statements by Rawls involve a claim for open borders directly, nor by implication, but we could stretch his theories and make it apply to the case at hand. Carens assumes that extension of Rawls' approach in the way he does, does not jeopardize the whole locus of Rawls' theoretical framework, but I think it does. In the first place Rawls supposes that his theory is a realistic utopia, in a sense that he recognises a closed system of states (as it is evident in western liberal societies) as a starting point of our analysis. Moreover, at a certain point in his description of the second original position, Rawls pointed out three ways in which the first and second original positions are disanalogous. (Ibid: 40$)^{1}$ I am not going to pursue Rawls' exposition here.

Thirdly, Carens holds that a utilitarian approach to the problem would favour much more open immigration than is a reality today. Under the utilitarian calculus nobody shall enjoy a privileged position that 'everyone is to count for one and no one for more than one'. And whatever the method of calculation, the claims of those who want to immigrate, given their number and dire situation, outweighs the claims of those who wish to keep them out. Therefore, a utilitarian approach to the problem, 'which takes the interests of aliens seriously' seems to favour free movement. To this I cannot object to the description, but only to say that it is not compatible with the liberal perspective Carens' advocacy fundamentally rests. One fundamental incompatibility may be attributed to the normative

\footnotetext{
${ }^{1}$ It implies that each is meant to fit together and any modification is apt to interfere with the system of thought in which each element is interconnected. In the first use of the original position, parties would choose principles that would lead them shape the basic structure of society. So they would find a closed political organ defined by territories a prerequisite before determining which principles they should choose to establish the basic structure. The second original position should not negate the assumptions made under the first choice situation. Thus it is not reasonable to assume that they would choose open borders.
} 
significance of rights in both traditions, which is that utilitarianism derives rights from utility while liberalism ascribes to some basic rights an intrinsic value.

In another article, Carens defended his position, this time, solely from a liberal egalitarian perspective. He offered three main arguments showing how freedom of movement is justified by and inherently attached to the underlying principles of liberal egalitarianism. One of the marked features of liberal egalitarianism is that it is founded on the idea that individuals should be free to pursue their own projects, make their own choices and be able to participate in determining their life chances. But they would not pursue their own projects unless they are free to move. In order to get access to the ways of realizing their life projects, they might be obliged to migrate to the place fitting their projects (professional, social, religious, economic or sentimental projects). Thus the presumption is to free migration as an important liberty. On this view, free movement is one essential element of the liberal egalitarian conception of justice with one obvious qualification- unless "the practice of open borders now would jeopardize those liberal egalitarian institutions and practices that currently exist and slow their development elsewhere". (Carens 1992: 28) The idea is that people should be free to immigrate so long as they do not actually threaten the sustainable existence of liberal institutions as Rawls' 'public order constraint' suggests. Obviously the host country is presumed to be liberal since people have good reasons to move to liberal societies, so is equally acceptable if one is to pursue his life goals in non liberal societies. What if the presence of liberal individuals poses a threat to the maintenance of non-liberal (but decent) institutions where the people subject to it value the most- say a theocratic decent society; would the public order constraint hold in this case, assuming that living under such institutions is essential for the people to pursue their projects? I suppose liberal egalitarianism respects distinctive ways of life other than its own, but appeals to particularity carry no moral weight when the institutions sought to be preserved are founded as a result of violations of basic human rights- as it is the case in most non-liberal societies. Thus liberal egalitarianism rejects restrictions on immigration on the grounds that it is essential to maintain non- liberal institutions (notably those falling below the criteria of minimum decency).

The other two considerations are: liberal egalitarianism is committed to equality of opportunity which freedom of movement would contribute to bring about; and free migration would reduce, if not eliminate, political and economic inequalities. Any redistributive arrangements for equalizing opportunity under the background of the current world order (provided the size and extent of potential demand and the lack of political will on the part of those capable of meeting those demands) is unlikely to hit its target; thus those who are in dire need should at least be able to move where the opportunities are. Of course that doesn't guarantee them an immediate access to opportunities because they have had unfair start in life and couldn't meet the meritocratic criteria of distribution which is firmly established in liberal tradition. Consider a person who has got no formal education because the opportunity was not there or was very limited, say he is from the developing world, and is free to immigrate to Western Europe. He could not be able to have real opportunities as he doesn't fit into the system in his new residence. The fact that immigrants in Western Europe sometimes involve in destructive activities may partly be explained- doesn't mean justified- due to the discordance between their high expectations 
and lack of technical expertise required to fit into the system. I think a mere procedural equality of opportunity, simply by opening borders and thereby render opportunities open to aliens, is a precarious solution to a difficult problem. Carens acknowledges a lack of clear policy guidelines on how to reduce global inequalities and that immigration will do little help, but this doesn't mean we should ignore the question of immigration because "[w]e have to consider the moral claims of those whom we confront here and now". (Ibid: 35)

\section{Arguments against Open Borders}

\section{Brian Barry's critique of the idea of free movement}

The idea of open borders, however, has received a wide range of objections. Now I will briefly sketch some of those objections that Carens has responded to: the 'brain drain' hypothesis and the backlash argument. I will take up his response to the communal argument in my discussion on Michael Walzer later in this paper. Those who prescribe to the 'brain drain' hypothesis maintain that the movement of people from the developing to the developed world actually worsens global inequalities because the more educated, physically fit and politically progressive are among the most likely to move to rich countries. Most of the people who move are the ones who are ambitious and economically able to pay for people smugglers. So, we could not rightly claim that immigration is to the advantage of the worse off. According to this position, free movement will make the situation worse, and it amounts to giving the licence to repressive regimes since open immigration would help them avoid the domestic pressure which history has proved effective for democratic change. I do share the concerns of those who advance the 'brain drain' hypothesis, but it is no argument for restricting movement owing to the widely shared principle that it is morally wrong to curtail one's liberty for the sake of better economic and political gains.

The other objection, termed as the backlash argument, seems to take the form of public order constraint discussed earlier in this article. According to this view, the commitment to open borders would instigate anti-immigrant sentiments in affluent societies. Citizens of affluent societies might object to the pressure immigrants impose upon the welfare system or perceive them as threats to the cultural distinctiveness of the society. Consequently, this reaction would erode tolerance which is at the heart of liberal societies. And in the long run the basic structure of liberal institutions would be in jeopardy. Currently we are witnessing practical indicators revealing that the danger is too near to ignore. In many states extreme right wing parties have gained popular support by advocating anti-immigrant policies and making them central to their campaign. Then, Carens asks a rhetorical question: would that justify restrictions on immigration from a liberal egalitarian perspective in which all people are regarded as free and equal moral persons? 'The answer must be 'no' at the level of principle and 'perhaps' at the level of practice...it is clear no justification at all at the level of principle though one cannot say that such concessions are never prudent in practice." (Ibid: 31, 32) 
Moreover, some would challenge the idea of open borders by drawing a distinction between freedom of exit and freedom of entry, claiming both are asymmetrical. Brian Barry counts one strong advocate of the asymmetry thesis. Freedom of exit must be absolute but that doesn't carry a right to enter any particular place. For Carens, it becomes lame in the face of the liberal egalitarian point of view, though there is something true about this claim. Carens' response is that freedom of exit is much more important than the right to enter but in most real life situations most people who are desperate to leave have nowhere to go and under such circumstances the conjunction of the two prevails. However, Brian Barry sees the 'nowhere to go' qualification as over-exaggeration, which doesn't reflect actual circumstances. To show its weakness, he reformulated the qualification as 'nowhere to go that they want to go'. He considers poor countries with open immigration policies as possible destinations for immigrants; but, he said, "[I] doubt if ... Carens would regard this as solving the problem. In my view neither the general proposition nor the specific application has the slightest plausibility”. (Barry 1992: 283) His proposal for immigration to other poor countries shows that Barry displays less concern, if not contempt, for hundreds of millions of people who live in morally regrettable situations. In this regard, I cannot offer conclusive answers concerning where to draw the line between what deserves moral concern and what does not. My impression is that basic human rights may serve as the bench mark, though there is a great deal of uncertainty on where to fix the threshold or if we ought to have a fixed threshold.

In response to the general argument for symmetry Barry calls upon the general trend of how associations or clubs operate: 'that almost all associations operate with an asymmetry between the entrance and exit.' Associations are usually established by setting up some criteria of inclusion and exclusion, otherwise there would be no need for having an association in the first place. Barry contends for asymmetry irrespective of the context or extent of application; and when it comes to the issue of migration he seems to oppose the idea of free movement, both intra-state and international, on the same grounds. Instead, he argues for redistributive policies aimed at reducing inequalities both at state and international levels. A long term strategy should include restrictions on immigration so as to bring economic development to the least developed while ensuring the legal and political rights to those who are subjected to it. Thus, he said, "from there being a presumption in favour of symmetry one has to say that there is a presumption in favour of asymmetry". (Ibid: 284)

However, Barry seems to agree with the analogy between internal and inter-state movement advanced by Joseph Carens. He then discredited both on the same ground, i.e. by prescribing to the asymmetry thesis. In order to disarm the asymmetry thesis, Carens came up with the distinction between private and public affairs which would, he believes, addresses the tension between freedom of association and the right to equal treatment. One way of solving the problem is to uphold that 'in the private sphere freedom of association prevails and in the public sphere equal treatment does'. The presumption is that migration is an issue which should be dealt with in the public sphere. An African-American doctor may not exclude white patients from his clinic, though he may do so from his summer beach house. Likewise, one must not exclude aliens from entering a given territory and take advantage of the social and economic system notwithstanding the right of individual 
citizens to keep them away from their private affairs. Of course Barry doesn't have objections against the analogy between domestic and transnational migration, he rather rejects the ground Carens offered to defend migration in both cases. Barry considers both internal and transnational migration as doing more harm than good.

I would, however, like to argue that Carens' stance for free movement in the domestic sphere is plausible while the application of the same argument to international migration does not appear defensible. In the domestic case there is good reason to suppose that citizens should be free to settle wherever they think fit to their plans of life. Movement within domestic territory is a right conferred upon individuals by virtue of being members of a political community which is designated under the notion of citizenship. No matter what local roots an individual may have and to whatever extent she identifies herself with the peculiar character of the local culture or religion, it will nevertheless be transcended by the notion of citizenship. So, the distinction between private and public sphere works behind the background of a defined political community. That is why we need the 'rule of law' to assign equal rights (to citizens) for the sake of which they have formed the political union. The telos of a state necessitates equal treatment of citizens within the defined territory. Conventional morality may dictate that we should treat all human beings as having equal moral worth, but that does not entail that restriction of migration violates this moral principle. It is one thing to argue for free migration across borders on purely moral grounds and another to defend it on political grounds. And it seems to me that Carens confuses the two. In the first place the idea of justice, or at any rate distributive justice, becomes sensible only when employed within the framework of a state. I concur with Rawls when he states 'justice is the first [though not the only] virtue of political communities'. It could be the case that justice sometimes conflicts with other virtues of political communities like beneficence, mutual benefit, national sentiments and the like, but claims of justice need not necessarily accommodate what the other virtues prescribe. Thus, moral claims have no ultimate bearing on what should be considered as a matter of justice. Unless Carens argues for some hard-line cosmopolitanism whose end is to create a world state, I suppose he doesn't, regarding open borders as the ideal, conflict with the notion of a state which we are familiar with.

Thus, it is a mistake to draw analogy between internal and interstate migration on the basis of public vs. private sphere. Besides, the public/ private distinction is contextual in a sense that it could be argued that any affair within the defined territory of the state is a private issue for the political community as such, and that immigration is a concern of the community as an entity. This does not mean that it is not objectionable if states slam their doors for immigrants. I think states are sometimes obliged to take in immigrants as a requirement of justice, especially when people are fleeing from political oppression or from civil war. Refusal to take these people amounts to actively violating their rights to live under humane conditions. The presumption is neither for open borders as Carens would have us believe nor for closed ones. Some modest immigration policy reforms aimed at aggressively dealing with legitimate claims of others for entry and integration should be sought. This requires defining which claims count as legitimate and which do not. I think it is very difficult to draw the line with precision; and even though we could reach at some general characterization of a legitimate claim, it would still be difficult in most cases to 
verify whether a piece of fact corresponds to the characterization of it. It is surrounded by subjective judgements, mostly motivated by vested interests and pre-established frames of mind.

But Carens regards some positive steps towards flexible immigration policy at best as a necessary step to a system of free movement. Free border is the ideal towards the realization of which current immigration policies should be aimed: as an ideal, free border sets the moral target. The underlying rationale behind this moral target, as Carens puts it, is the presumption that freedom of movement is a fundamental human right. None of the arguments he offered justify the general claim that freedom of movement is a fundamental human right.

\section{Commentary on Libertarianism and Transnational Migration of People}

The following is Onora O'Neill's impressive commentary on Steiner's libertarian conception of transnational migration. O'Neill challenges the idea of pure property rights and freedom of contract independent of state powers. For libertarians, property rights are absolute and the only role states should play is legitimizing and thereby providing legal protection for private property. At the heart of this contention lies the claim that individuals' moral rights precede the state and that the legitimacy of a state is derived from the rights of individuals (abstracted from natural, social, and historical contingencies). O'Neill argues for two claims: first, granting Steiner the claims he espoused, we ended up having more restrictive immigration policies than the one currently in order; and second, the underlined conviction of libertarians misses the point for it rests on a "foundational myth" concerning the initial situation (or state of nature). According to Steiner, the only legitimate restrictions on movement are those constraints imposed by individual property owners on access to their property. Moreover, public provision of goods is unthinkable in the Steinerian world. Thus, "in a world without public provision or public spaces [migration policies] could be infinitely more restrictive than immigration and emigration constraints now imposed by states." (O’Neill 1992: 117)

In fact Steiner considers original titles, though legitimate, as encumbered and it presupposes an obligation to compensate those excluded from the original act of appropriation. Compensation may be translated into access to the territories and opportunities within; but this doesn't lead to the direction of compensation to the poor in the form of free migration and settlement. This is because poverty and other active causes for movement of people are not direct consequences of exclusion 'from inherited shares deriving from original appropriation'. (Ibid) ${ }^{2}$ Secondly, O'Neill notes that a resort to

\footnotetext{
${ }^{2}$ Perhaps one may argue that poverty is an effect of unjust transfer of property entitlements and that the claims of those who need to immigrate derive its legitimacy from that. If one argues this way, then he should demonstrate the connection between the allegedly unjust historical moment and the plight of the world poor. Nevertheless, as a contemporary variant of the Lockean contractarian theory, in libertarianism land (along with its fruits) plays a central role and considered as the one worthy of entitlement. In this regard, who among the destitute in Africa has a legitimate property right in Western Europe? As O'Neill has put it, "[c]ompensation for exclusion for inheriting the fruits of original appropriation is not equivalent to compensation [remedy] for present poverty”.
} 
universal principles has to be understood as historically embedded as well as dependent upon the political reality of the time (including a particular notion of state), which necessitates the very being of those principles. The idea of the individual is inseparably tied with the idea of the state and both reinforce each other. So it is very difficult to say one has moral precedence over the other, or that one is derived from the other. The following quotation summarizes the above idea: "just as we cannot abolish the distinction between legitimate and illegitimate births unless we abolish marriage, so we cannot abolish distinctions between citizens and non-citizens unless we abolish the plurality of states". (Ibid: 119) Liberal citizenship provides a stronger basis of identity inclusive of other differences, much more than being a matter of preference as libertarians would have it. Thus, to abandon citizen/alien distinction is to destroy the basic principles that both give life to and nurture- the very idea of the state or the political.

\section{The Communitarian Challenge to Open Borders}

Perhaps, no contemporary political theory provides an impressive discussion on the relationship between the question of membership and distributive justice than the one we find in Michael Walzer. He asserts that questions of distributive justice presuppose a territorially 'defined world within which distributions take place'. What are the sorts of things to be distributed? Distributive justice primarily deals with distribution of membership, but not among us, it is already ours. The issue of membership arises only among people who do not share a common political life. Walzer is not interested in the historical origins of membership but in the way it operates. Distribution of membership depends on the collective understanding of current members concerning the meaning of membership and what sort of community they wish to maintain. But the right of communities to exclude strangers in the name of self-determination is constrained by 'the principle of mutual aid'. (Walzer 1983: 33) ${ }^{3}$ Apart from conventional morality, the philosophical basis for this principle is not clear to Walzer and he doubts that it could be a counterfactual assumption about what a society would look like in the absence of this principle. People who share a common life often have much stronger sense of attachment, which sets the context for stronger duties to fall upon each other. But mutual aid comes in

\footnotetext{
${ }^{3}$ In this regard, Walzer follows John Rawls in which the full exposition of the notion is found in A Theory of Justice and in The Law of Peoples with some modifications. The notion of 'mutual aid' or 'duty of assistance' dictates the obligation of well ordered societies to assist societies burdened by unfavourable conditions. The idea is that, had it not been for the unfavourable conditions, these societies would have attained the level well ordered societies enjoy. And the purpose of this duty is to lift the obstacle which prevents them from attaining the required level of decent life. Nowhere in the general idea nor in its particular formulation could we find a direct implication for immigration policies. I doubt that this duty would better reach its target simply by admitting immigrants from burdened societies, Rawls' theory did not suggest that either. But Walzer seems to follow the idea seriously, that he wants to "point to mutual aid as a (possible) external principle for the distribution of membership, a principle that doesn't depend upon the prevailing view of membership within a particular society".
} 
only in the absence of common identity or cooperative schemes. He mentions two cases where issues of admission could not arise: when there are no membership categories- like in a world where there are no political communities, states or municipalities on the one hand; and if there is a global state which distributes membership equally on the other. Both cases are very far from feasibility in the world we live.

Current admission policies are shaped by economic and political concerns of the host state and partly by 'arguments about the character of countries (political communities) in general'. Arguments from essential character of political communities are of high theoretical relevance. Since we don't have direct experience of political communities- "we actually see only its symbols, offices and representatives"- it is very difficult to spell out what is meant to be member of a political community. Walzer wants to unveil the meaning of political membership using comparisons with neighbourhoods, clubs and families. He maintains that by way of comparison, we could have a fairly comprehensive account of what political membership constitutes. The neighbourhood is a random collection of people who happen to live in close proximity due to life accidents. It consists of people who moved in for various reasons including those who chose to be there in search for job, to rent cheap apartment, for healthy environment, etc. Generally neighbourhoods do not admit or exclude, but new comers may be welcomed or not welcomed. Clubs differ from neighbourhoods in the sense that they institute admission criteria. Like clubs, states can regulate admissions but not withdrawals. For admissions they may take cultural, linguistic and political resemblance into account but that doesn't imply that national disresemblance could be a ground for expulsion. Walzer confirmed that "though the recognition of national affinity is a reason for permitting immigration, non-recognition is not a reason for expulsion". (Ibid: 42)

The admission of millions of Germans who were expelled from Poland after the end of the Second World War to Germany is an indication that states are more than clubs: they resemble families in this regard. But unlike families, states are bounded by a defined territory because the national identity states are presumed to uphold is a combination of people and land. Thus admissions might be guided by affinity between current members and the ones who seek to join them, but it can, however, be overridden by the principle of mutual aid. On the one hand, Walzer would have us acknowledge that immigration is a matter of political decision; and on the other hand, mutual aid is a more coercive moral principle for political communities than it is for individuals because the marginal effects of benevolence done at the communal level is much less costly than when it is done at individual level. Thus admission of strangers does not necessarily entail "the kinds of intimacy that could hardly be avoided in the case of clubs or families".

When it comes to the issue of refugees in particular, Walzer gave more emphasis to ideological affinity. Commitment to liberal values generates bonds of connection across national borders, and anyone who faces persecution or who is denied freedom for defending democratic values "is a moral comrade of a liberal citizen". Liberal societies have a duty to receive like- minded comrades who are victims of authoritarianism. In case where there is no connection whatsoever with particular victims, then there can't be a criterion at our disposal to prefer them over others equally in need. To take in as much as the society could accommodate without fundamentally affecting the distinctiveness of the 
political community is morally required; "but the right to restrain the flow remains a feature of communal self-determination". Moreover, "the principle of mutual aid can only modify, and not transform, admissions policies rooted in a particular community's understanding of itself”. (Ibid: 51) If mutual aid is not of stringent constraint on communal self-determination, crossing the line in the name of self-determination wouldn't necessarily be objectionable. For defining what counts as an act of mutual aid lies within communal self-determination and hence by itself an embodiment of the latter. Consequently, communal self-determination maintains an absolute value. Yet, there are and should be limits to self-determination more than what communitarians are ready to accept. Constraints to communal self-determination, as it is advocated by communitarians, may take up a form of redefinition to the notion of political communities and the meaning to membership to such communities. One may seek a definition more inclusive to racial, ethnic, religious, cultural and if you may civilizational disparities. It is this inclusive multicultural notion of political membership that animates the contention: "in spite of our differences, we are all Americans". Membership to political communities so broadly defined, thus overcomes the limitations to the communitarian take on transnational migration. Communitarians prioritize 'family' affinity and cultural similitude as viable grounds for taking in immigrants, but this runs the risk of reactivating the age old aristocratic sentiment against which modernity and rationalism have fought concerted struggles.

Before closing the discussion on Walzer, let me briefly summarize the points he made. First, self-determination is a core attribute of political communities without which there could not be historically stable 'communities of character' with special commitment to each other and the aspiration to lead a common life for an indeterminate future. However, selfdetermination is not absolute: it is constrained by the principle of mutual aid. Second, the denial of membership to aliens and guest workers who have already begun the journey of life within the community is not an expression of communal freedom but of oppression and tyranny. The idea is that citizens can not exercise territorial jurisdiction against those with whom they share the territory; doing so amounts to acting outside 'the spheres of justice', beyond their legitimate rights. In other words, the moral legitimacy of state borders is derived from equal treatment of all who live within. Once aliens are effectively integrated into the communities in which they live, there is no reason to deny them the status that comes with membership, notably citizenship. Finally, Walzer remarks: "[t]he theory of distributive justice... must vindicate at one and the same time the (limited) right of closure, without which there could be no communities at all, and the political inclusiveness of the existing communities". (Ibid: 63) Political inclusiveness is, however, incompatible and occasionally in tension with commonly held idea of integration. Integration is supposed to require new arrivals to try to fit into the cultural mind set of the communities they joined. The question is though: should non-integration be a ground for depriving them of membership? Does justice require immigrants subscribe to the new way of being more than what is required to lead their daily life? The answer must be no, simply because a 'yes' would mean violation of their rights. I cannot pursue this argument in detail, only to presume that the validity of its claim is widely familiar. 


\section{Immigration and the Legitimacy of State Borders}

The emergence of modern nation states brought about the creation of jurisdictional zones. State boundaries mark not only where citizenship rights and privileges end but also where the powers of the law in regulating people's behaviour are fixed. The issue of immigration is, thus, inseparably tied to the question about the moral legitimacy of state borders. One can hardly argue for open immigration without first undermining the moral value of state borders. People who move across borders for permanent settlement do not only shift political communities but also legal systems. Once moved and settled, they will be subject to the domestic law which rules over citizens impartially. The legitimacy of the law is in turn derived from the shared moral values of the community (shared moral values should not necessarily reflect one distinct culture unless in a cohesive society) as well as from the states' effective control over the defined territory. It follows that, if state borders are unimportant, so is the law which is bounded within state borders. This shall not be the caseboth theoretically and practically, so long as we live in the world divided by states. If one endorses the current world order and thereby encourages the replication of western model liberal nation states elsewhere in the world, she must at the same time recognize the legitimacy of state borders. In this regard, Carens' argument for open borders is incomplete because the claims he espouses have left the legitimacy of particular legal systems unaffected. In other words, he argues for open borders while leaving the domestic law function within 'illegitimate' state borders. I think his position is marred by inconsistency. This is not meant to defend communitarian advocacy for absolute right to communal selfdetermination. What I want to stress is that the idea of open borders and delicate liberalism are mutually exclusive.

On the other hand through treaties and involvement in multi-state organizations like the UN, EU, AU, and NATO, states have relinquished some part of their sovereignty and allow treaties, universal declaration of human rights and public international law to govern their behaviour. Through their sovereign act and declaration of will to be bound by treaties, the UN charter, and other provisions of international law, states have compromised their sovereignty. State boundaries will no longer have absolute value and may sometimes be overridden by stronger claims for entrance. So long as the value of state borders is not fundamentally eroded and that we still cling to special values of membership, immigration will continue to pose moral and political dilemma.

\section{A Word on the 'Brain- Drain' Hypothesis and the "Developing World Point of View"}

Few words about the so called 'brain-drain' hypothesis are in order. Two pertinent reasons why the need to discuss it in a separate section have particularly caught my attention. One reason is tied to the attitude, or at any rate a value judgement, preoccupying the thoughts of many scholars from the developing world, which is that the West is solely responsible for snatching skilled human capital from less developed countries. Behind this conviction lies 
a belief in its unwavering empirical truth, which I believe demands serious empirical research, and a subsequent normative judgement over the phenomenon. I shall set aside the empirical ground, albeit extremely necessary, only to show the flaw in reasoning that has marked the theses for 'brain-drain'. Second, I felt the urge to discuss the place of brain drain in a wide framework of rights as conceptualised in political philosophy. One issue that has sparked an all front debate was the perceived conflict between group and individual rights: questions concerning whether the conflict was real, how they can be reconciled or be traded-off or in general what justice requires in this particular case. In this paper I shall not content myself to resolve the tension between group and individual rights, but as I have argued elsewhere any right worthy of the name shall finally rest on the individual. (cf Mekonnen: 2006) It could, however, be argued that group rights may have a standing independent of individuals constituting the group in question. Such rights are often perceived to have a negative character, mostly as a set of prohibitions. Rights in general may appear in either of the following two forms. One, a right could be formulated as: $\mathrm{X}$ has a right to do $\mathrm{A}$ in circumstance $\mathrm{C}$ and $\mathrm{Y}$ has an obligation not to interfere in the exercise of $\mathrm{A}$. And second, $\mathrm{X}$ has a right to do $\mathrm{A}$ in circumstance $\mathrm{C}$ and $\mathrm{Y}$ has an obligation to provide necessary conditions for the realisation of A. Following Isaiah Berlin's classification, the first could be called a negative right while the second positive right. Now, group rights appear to be negative in most of the cases if such rights are claimed against individuals not belonging to the group. I may have obligations to respect the right bestowed upon groups as a collective, say not to impede people from exercising their religious and cultural practices. But such a prohibition is instructive in my dealings with individuals for I can't see the group as such. Thus it is plausible to claim that group rights manifest in individuals identified as being constitutive of the group. However, it might be the case that the individual may refuse to identify herself with the group she supposedly belongs to. Will the group, then, have a right to demand or at any rate enforce allegiance against that particular person? The answer must be no. This is exactly the point where individual rights get primacy.

Similarly, a nation may not force individuals not to leave; this is beyond its sphere of rights. It should be noted that it is indeed morally objectionable if individuals refuse or fail to give back to the society. This doesn't mean the society has a corresponding claim right against such individuals. One distinctive feature of rights as opposed to moral imperatives is that they are institutionally enforceable. Contrariwise, in spite of moral constraints, individuals' freedom of existence is and should be absolute. Regardless of the nature of the state, it is imperative that a plausible conception of social justice should contain provisions that bestow rights to individuals to choose their life goals and thus individuals must be free to move to a place fitting their projects provided that they are welcome in their new place of residence. The 'brain-drain' hypothesis, viewed in this light, shall lose its force. But it could still remain a moral argument, perhaps a plausible one. As I have noted before, citizens' (specially educated elites) moral obligation to serve the society in which they are raised, or rooted in if you may, remains intact. Proponents of the 'brain-drain' hypothesis, however, have exploited this undeniable moral responsibility and have tried to apply it in the realm of rights. This is the point where, I think, they got it wrong. 
Adherents of the 'brain-drain' hypothesis may resist not my account of rights but the characterisation of the responsibility to reciprocate the society's deed to them. They do so by asserting that it is an enforceable obligation. Obviously the basis for its enforceability is benefit: one is obliged to reciprocate because one has benefited from it. Does benefit provide a plausible ground for a corresponding claim right? Does the fact that I have benefited from the system, either voluntarily or involuntarily, release others from the obligation of not forcing me to give benefits back? Now, I am getting at the principle of fairness that Herbert Hart and John Rawls have long been advocating. For them society is a cooperative venture which functions in accordance with the principle of fairness- without which its existence is self-defeating, and this underlying view explains why Rawls calls his theory of justice as 'justice as fairness'. I am aware of not doing justice to Rawls' position simply because this short paper is not fit to address the complexities in Rawls' conceptualisation. I thus advise the reader to make reference to his ground breaking work, "A Theory of Justice", where one could find a complete picture of Justice as Fairness. The principle of fairness, in its less objectionable form, would not preclude the need for individuals' consenting to cooperate in advance. To return to the issue under consideration, no matter how fairness consideration requires individuals to give service to other fellow citizens it must not be that the state has a corresponding right either to demand or to free them of this obligation. At this juncture, I want to reaffirm that the 'brain-drain' hypothesis runs into difficulties when used as a prima facie case for migration restrictions. After all, membership to political associations is not as absolute, with no exit rights, as communitarians would have us believe. Individuals have rights, and the state serves as a safeguard of their rights. In so doing the state may limit the rights of some or all when imperative conditions so demand, for instance when the very survival of the state is at stake. And this may be justified through 'individual right' writ grounds by recognizing that individual rights become actual only in the state ${ }^{4}$. (cf Hegel 1952)

However, it is my contention that freedom of exit is constituent of the existence of an individual as a free and autonomous being. Here I follow the two possible meanings of autonomy G.A. Cohen has brought to the fore. Autonomy could be defined, on the one hand, in terms of the range of options an individual has in a given choice situation, and on the other, the individual is said to be autonomous in so far as he is the author of his own actions. Regardless of which sense of the term is used, individual autonomy will inevitably be curtailed if limits to freedom of exit are instituted by the state. One likely ground for limiting freedom of exit (by less developed states) could be reasons pertaining to the ever accelerating 'brain-drain'. But once freedom of exit is established as constitutive to individual identity (surely there are conceptual as well as normative controversies surrounding the notion of personal identity, and I shall set that aside for the purpose of this paper), the 'brain-drain' hypothesis- as a case for limiting freedom of exit- shall lose its perceived appeal.

\footnotetext{
${ }^{4}$ Hegel's claim that the idea of freedom becomes actual only in the state is extremely instructive. As Hegel has it, abstract right soon enters the process of concrete existence the moment the individual enters social relations. This relation begins with property rights and subsequent contractual relations, and culminates in membership to a state.
} 
Empirical studies show that approximately 65,000 African born physicians and 70, 000 African born nurses were working in the developed world in the year 2000. This number constitutes one fifth of the overall African born health professionals. No specific research, which I am aware of, has been undertaken in estimating how many health professionals East Africa in particular has been ripped off each year. The flow of professionals from Africa to developed countries in an alarming rate is what a sane person can hardly deny. But whether it is appropriate to call it 'brain-drain' is what I take an issue with. And secondly, would the 'brain-drain' situation outweigh the 'brain-wastage' which I think is more serious had African intellectuals remained within their national boundaries? Most of the professionals so mentioned are western educated elites of whom Africa could not rightly claim for exclusive entitlement rights over their 'brain'. Besides, contemporary situations made it possible for African professionals to contribute in a more efficient and concerted manner for the betterment of their country of origin. Thus, when it is said that 'brain-drain' is merely negative as the very naming suggests, one has to consider other conditions that weigh against it.

Finally, I wish to remind my reader that I do not pretend to give a causal account for the so called 'brain-drain' hypothesis, nor should I discredit the connection between economic development and human capital. If correct, my arguments demonstrate that migration restrictions cannot be justified owing to 'brain-drain' considerations. The room is still open, were we to make a case for principle/s of justice that permit restricting the individual's right to move and settle where he/she wishes to. The burden of proof lies on those who wish to prescribe to the claim that restrictions on freedom of exit are consistent with a plausible conception of justice. The discourse will then trickle down to the question whether the conception of justice they would advance is coherent or plausible. Surely, minimizing conceptual obscurities will add up to the ongoing effort to synthesise a more plausible conception of justice.

\section{References}

Barry, Brian. 1992. The Quest for Consistency: A Sceptical view. In Barry, B, and R. E. Goodin, editors. Free Movement: Ethical issues in the Transnational Migration of People and Money. Pennsylvania: Pennsylvania University Press

Carens, J. H. 1995. Aliens and Citizens: A Case for Open Borders. In W. Kymilcka, editor. The Rights of Minority Cultures. Oxford: Oxford University Press

Carens, J. H. 1992. Migration and Morality: A Liberal Egalitarian perspective. In Barry, B. and R. E. Goodin, editor. Free Movement: Ethical Issues in the Transnational migration of People and Money. Pennsylvania: Pennsylvania University Press

Hegel, G. W. F. 1952. Outlines of the Philosophy of Right translated by T. M. Knox. Oxford: Oxford University Press

Mekonnen, K. 2006. Phenomenology of Freedom: From Western Existentialism to contemporary Ethiopian Experience. Unpublished B. A. Thesis 
O’Neill, O. 1992. Commentary: Magic Associations and Imperfect people. In Barry,B B. and R. E. Goodin, editor. Free Movement: Ethical Issues in the Transnational Migration of People and Money. Pennsylvania: Pennsylvania University Press

Rawls, J. 1971. A Theory of Justice. Cambridge, M. A.: Harvard University press

Rawls, J. 1999. The Law of Peoples with the Idea of Public Reason Revisited. Cambridge, M. A.: Harvard University press

Steiner, H. 1992. Libertarianism and the Transnational Migration of people. In Barry, B. and R. E. Goodin, editors. Free Movement; Ethical issues in the Transnational Migration of people and Money. Pennsylvania: Pennsylvania University Press

Walzer, M. 1983. Spheres of Justice: A Defence of Pluralism and Equality. Oxford: Oxford University Press 